\title{
СИСТЕМНИЙ АНАЛІЗ АКТИВНОСТІ МІКРОРНК ПРИ ПУХЛИННОМУ ЗРОСТАННІ
}

\author{
О. П. Мінцер, В. М. Заліський, Є. А. Малярчук \\ Національна медична академія післядипломної освіти імені П. Л. Шупика
}

\begin{abstract}
Концептуалізовано дані щодо ролі мікроРНК. При аналізі можливих стратегій відновлення нормального рівня р53 і р53залежних від мікроРНК із метою профрілактики злоякісних новоутворень висловлено припущення, що виявлені фракти змінили розуміння експресії генів і створили прецедент для розроблення нових методів діагностики та лікування раку. Представляється важливим виявлення додаткових потенційних мішеней мікроРНК і розроблення безпечних методів лікування на основі мікроРНК із тим, щоб модуляція мікроРНК стала критичним методом для лікування раку. У цьому плані становить інтерес вивчення варіантів протиракової терапії, пов'язаних із одночасною гіперактивацією двох регуляторів апоптозу p53 і мікроРНК. У рамках прийнятого математичного моделювання показано потенційно високу антибластомну терапію, мішенню якої є білок-інгібітор р53 як основна ланка петлі позитивного зворотного зв'язку р53 — мікроРНК, а також ініціації метастазування пухлин. Зроблено висновки: 1. МікроРНК являють собою найважливіші регулятори клітинного диференціювання, проліферації і виживання. Зміни в експресії мікроРНК явно пов'язані з прогресуванням численних захворювань людини, зокрема, раку. 2. МікроРНК виконують ключову роль у генезі пухлин як важливі модулятори/демодулятори в клітинних шляхах, регулюючи експресію гена цілі через репресію перекладу або погіршення mRNA. Oтже, мікроРHK $є$ привабливими кандидатами на роль прогностичних біомаркерів і терапевтичних мішеней при раку.
\end{abstract}

Ключові слова: некодуючі РНК, мікроРНК, транспозони, геномна нестабільність, альтерація генів онкосупресорів, активація онкогенів, мутації, математичне моделювання, епігенетика.

\section{SYSTEMIC ANALYSIS OF MICRORNAs ACTIVITY IN TUMOR GROWTH}

\author{
O. P. Mintser, V. M. Zaliskyi, Ye. A. Malyarchuk \\ Shupyk National Medical Academy of Postgraduate Education
}

Background. Some data on the role of miRNAs are conceptualized. When analyzing possible strategies for restoring the normal level of p53 and p53-dependent microRNAs in order to prevent malignant neoplasms, it was suggested that the detected veils changed the understanding of gene expression and set a precedent for the development of new methods for the diagnosis and treatment of cancer. It is important to identify additional potential microRNAs targets and develop safe microRNA-based treatment methods so that microRNAs modulation becomes a critical method for the treatment and treatment of cancer. In this regard, the studied variants of anticancer therapy associated with the simultaneous hyperactivation of two apoptosis regulators, p53 and microRNAs, are of interest.

Materials and methods. Results. Within the framework of the accepted mathematical modeling, a potentially high antiblastoma therapy is shown, the target of which is the p53 inhibitor protein as the main link of the p53 positive feedback loop-miRNA, as well as the initiation of tumor metastasis. Conclusions are drawn: 1. MicroRNAs are the most important regulators of cell differentiation, proliferation, and survival. Changes in miRNA expression are clearly associated with the progression of numerous human diseases, in particular cancer. 2. MicroRNAs play a key role in the genesis of tumors as important modulators/demodulators in cell pathways, regulating target gene expression through repression or mRNA degradation.

Conclusions. MicroRNAs are attractive candidates for the role of prognostic biomarkers and therapeutic targets in cancer.

Key words: non-coding RNAs, microRNAs, transposons, genomic instability, damage of genes oncosuppressor, oncogenic activation, mutations, mathematical modeling, epigenetic. 


\title{
СИСТЕМНЫЙ АНАЛИЗ АКТИВНОСТИ МИКРОРНК ПРИ ОПУХОЛЕВОМ РОСТЕ
}

\author{
О. П. Минцер, В. Н. Залесский, Е. А. Малярчук \\ Национальная медицинская академия последипломного образования имени П. Л. Шупика
}

\begin{abstract}
Концептуализированы данные о роли микроРНК. При анализе возможных стратегий восстановления нормального уровня р53 и р53-зависимых от микроРНК с целью профилактики злокачественных новообразований высказано предположение, что обнаруженные фраты изменили понимание экспрессии генов и создали прецедент для разработки новых методов диагностики и лечения рака. Представляется важным выявление дополнительных потенциальных мишеней микроРНК и разработка безопасных методов лечения на основе микроРНК с тем, чтобы модуляция микроРНК стала критическим методом для лечения рака. В этом плане представляют интерес изученные варианты противораковой терапии, связанные с одновременной гиперактивацией двух регуляторов апоптоза - p53 и микроРНК. В рамках принятого математического моделирования показана потенциально высокая антибластомная терапия, мишенью которой является белок-ингибитор p53 как основное звено петли положительной обратной связи р53 - микроРНК, а также инициации метастазирования опухолей. Сделаны выводы: 1. МикроРНК представляют собой важнейшие регуляторы клеточной диффееренцировки, пролиферации и выживания. Изменения в экспрессии микроРНК явно связаны с прогрессированием многочисленных заболеваний человека, в частности, рака. 2. МикроРНК выполняют ключевую роль в генезисе опухолей как важные модуляторы/ демодуляторы в клеточных путях, регулируя экспрессию гена цели через репрессии перевода или ухудшение mRNA. Таким образом, микроРНК являются привлекательными кандидатами на роль прогностических биомаркеров и терапевтических мишеней при раке.
\end{abstract}

Ключевые слова: некодирующие РНК, микроРНК, транспозонов, геномная нестабильность, альтерация генов онкосупресорив, активация онкогенов, мутации, математическое моделирование, эпигенетика. 
Вступ. Протягом десятиліть дослідження в галузі біології раку були зосереджені на ретельному вивченні генів, що кодують білки. Тільки недавно було виявлено, що цілий клас молекул, які називаються некодуючі РНК (мікроРНК), відіграє ключові регуляторні ролі у формуванні клітинної активності. Вибух досліджень в області біології мікроРНК із тих пір показав, що вони являють собою різноманітну та поширену групу РНК, включаючи як онкогенні молекули, так і ті, які працюють в якості супресора пухлин [13].

МікроPHK (miRNAs/miRs) були ідентифіковані в 1993 році [1]. Це тип малих некодуючих РНК, довжиною від 19 до 24 нуклеотидів, що виконують важливу роль у регуляції експресії генів на посттранскрипційному рівні. МікроРНК діють шляхом деградації своїх РНК-мішеней або придушення трансляції мРНК [2]. В останні два десятиліття численні дослідження показали важливу роль мікроРНК у регуляції найважливіших клітинних процесів, включаючи проліферацію, диференціювання, міграцію, апоптоз, метаболізм і реакцію на стрес [3]. Було продемонстровано, що мікроРНК діють як ключові регулятори в патогенезі захворювань [4-6], особливо при раку. Раніше було виявлено, що > 50 \% генів мікроРНК розташовано в асоційованих із раком областях геному та утворюють центральні вузлові точки в шляхах розвитку раку (> 5). Останнє дозволяє припустити, що мікроРНК може відігравати важливу роль у патогенезі раку людини. Гіпотеза про те, що дисрегуляція мікроРНК може відігравати фундаментальну роль у виникненні, прогресуванні та поширенні численних типів раку, була в першу чергу підтверджена при хронічному лімфоцитарному лейкозі (ХЛЛ) Calin et al. [7], який продемонстрував, що miR-15a та miR-16-1 були знижені або видалені у більшості пацієнтів із ХЛЛ.

На сьогодні ключовими механізмами канцерогенезу визнані епігенетичні події (метилювання ДНК, ацетилювання гістонів, експресія мікроРНК) і вища хроматинова організація). Відповідно до останніх даних, некодуючі РНК (мікроРНК, малі інтерферуючі РНК або si PHК, рі РНК, довгі некодуючі РНК або Inc PHK) в більшості своїй або безпосередньо утворюються з мобільних генетичних елементів, або мають транспозонне походження.

Некодуючі РНК специфічно впливають на метилювання генома, ацетилювання (модифікацію) гістонів, чому сприяють еволюційно запрограмовані особливості активації транспозонів із послідовностей яких походять розглянуті мікроРНК.

Під дією стресу та при старінні збільшується ймовірність розвитку онкопатології, що пояснюється підвищеною ймовірністю активації мобільних генетичних елементів, чутливих до стресу та змінення рівня гормонів. Аномальна активація транспозонів у клітинах веде до геномної нестабільності, що просуває їх до апоптозу. Однак, прогресуюча геномна нестабільність веде до активації генів онкосупресорів і активації онкогенів у результаті атоптоз не відбувається, а клітини знаходять здатність до неконтрольованої проліферації з накопиченням безлічі мутацій через мобілізацію транспозонів і прогресуючу геномну нестабільність. Встановлено, що в кожному плечі злоякісних пухлин запускаються свої каскадні механізми мобілізації транспозонів за участю некодуючих РНК. Тому дослідження епігенетичних механізмів розвитку кожного типу раку може призвести до розроблення ефективних методів ранньої молекулярно-генетичної діагностики онкопатології, а також таргетної терапії на різних стадіях розвитку патологічного процесу.

В результаті проведення сотень клінічних випробувань, орієнтованих на злоякісні новоутворення, за участю мережі-асоційованих мікроРНК, в якості нових біомаркерів або таргетних молекул сформовано напрями в онкології [8]. МікроРНК, у свою чергу, регулюється ефекторами епігенічної системи, такими як ДНК-метилтрансфераза (DNMT), гістонова дефцетилаза (HDAC) і генами репресивного комплексу Polycomb. Повногеномний аналіз різних типів пухлин показав вплив метилування ДНК і модифікації гістонів на глобальне регулювання мікроРНК. При цьому, такі мікроРНК побічно впливають на експресію генів онкосупресорів, чия експресія контролюється іншими енергетичними факторами [9].

Мета роботи: концептуалізація основних експериментальних даних щодо ймовірної ролі мікроРНК у пухлинному зростанні.

Результати та їх обговорення. Аномальному метилюванню генів як причини онкогенезу останнім часом відводиться все більша увага. Для багатьох пухлин було показано, що порушення метилювання не обмежується одним геном, а може зачіпати одночасно відразу декілька генів. 345000 $\mathrm{C}_{\mathrm{p}} \mathrm{C}_{1}$ - острівців, наявних у геномі людини, одночасно гіперметильованими можуть виявитися в середньому 600 із розкидом від 0 до 450 
в окремих неоплазмах із одночасним зростанням частоти мутацій. Більш того, виявилося, що в нормальних клітинах має місце локальне гіперметилювання деяких генів - феномен, пов’язаний зі старінням [10].

Існує безліч джерел геномної нестабільності при злоякісних новоутвореннях, починаючи від впливу навколишнього середовища до ендогенної генерації ракових метаболітів, що ушкоджують ДНК. Крім того, геном людини несе в собі безліч тангенціальних інтерсекційних мутагенів транспозонів («transposable element 9, TE») [11]. Численні свідчення про ретротранспозиції в соматичних тканинах дають підставу припустити, що кожен індивідуум малозначний по геномним перебудовам завдяки мобілізації транспозонів у певних клітинних популяціях.

Транспозони поділяються на ДНК — ТЕ (міститься менш ніж 2 \% геному і ретро — TE) [8]. Ретро TЕ класифікуються на LTR (Long Terminal Raped) - довгі кінцеві повтори, дисперговані елементи — LINE — елементи кодують зворотну транскриптазу, тоді як SINE не автономні та залежать від білків, що кодують LINE для реплікації та інтеграції. LINE-1 сприяють ретротранспозиціям неавтономних SINE - елементів, таких як Alu, змінюючи таким чином структуру генома незліченними способами.

Механізми, відповідно до яких мобілізація транспозонів веде до потенційно шкідливих мутацій, дуже різноманітні. Транспозони (головним чином Alu) мають велике представництво гомологічних нуклеотидних послідовностей, розсіяних по всьому геному, що може призвести до неалельної гомологічної рекомбінації (NAHR — non-allelic) NAHR — індукованих мутацій у пухлинах людини.

Відомо, що білок р53 відіграє ключову роль у придушенні розвитку пухлин. До 80 \% пухлин у людини пов'язані з порушеннями функції р53 [14], що дозволяє розглядати р53 як перспективну мішень для терапії злоякісних новоутворень людини. Будучи транскрипційним фактором, p53 регулює транскрипцію багатьох генів, контролюючи тим самим безліч біологічних процесів, включаючи репарацію ДНК, клітинний цикл, апоптоз, старіння та метаболізм.

Серед мішеней р53 є не тільки гени, що кодують білки, а й гени, що кодують мікроРНК [13, 14]. Зазвичай мікроРНК знижують рівень матричних РНК-мішеней. Однак у ряді випадків показано, що комплекси з певними мікроРНК-зв'язуючими білками можуть збільшувати експресію генів-мішеней [2]. Білок р53 може активувати або репресувати транскрипцію генів мікроРНК або надавати опосередкований вплив на біоценоз мікроРНК, регулюючи експресію компонентів молекулярних комплексів, що забезпечують дозрівання мікроРНК [24].

Транскрипційний фактор р53 знаходиться під складним контролем із боку цілого ряду позитивних і негативних регуляторів р53, у свою чергу, модулюється через р53-залежні механізми, що призводить до формування складної системи позитивних і негативних зворотних зв’язків. Функціонування молекулярної мережі, що управляє активністю р53 сьогодні інтенсивно вивчається в зв’язку з пошуком ефективних маркерів і терапевтичних цілей при онкологічних захворюваннях. При цьому всі нові дані свідчать про значну роль р53-залежних мікроРНК у цих регуляторних контурах [14].

Великий інтерес, зокрема, викликають діючі через інгібітори р53 позитивні зворотні зв'язки мікроРНК-мішеней із р53. Детальну взаємодію показано для p53 і таких його мішеней, як let-7 [15], miR-156 [16, 17], miR-16 [18], miR-342 [19], miR-143/145[20], miR-192, -194, -215 [21], miR-221 [22], miR-335 [23], miR-603 [24].

Важливо відзначити, що деякі зі згаданих мікроРНК здатні пригнічувати розвиток пухлин через р53-незалежні механізми. До них відносяться, зокрема, let-7, miR-156, miR-16, miR-29, miR-34a, miR-145, miR-192, miR-215 [20]. Всі згадані мікроРНК, знаходяться в позитивній залежності від p53 і пригнічують активність будь-якого інгібітора p53. Особливий режим функціонування систем такого роду описується в літературі як синергія, а результатом $є$ істотне та одночасне зростання рівнів (або активності) p53 і мішені. У подібній ситуації можливий запуск програми атоптозу або незворотного припинення поділу (старіння) для терапевтичного впливу на пухлинні клітини [21].

Інтерес представляє використання мікроРНК як предикторного фактора. Виявлено патерни експресії мікроРНК для прогнозування результату та прогнозу розвитку раку. При раку молочної залози було продемонстровано, що 31 мікроРНК були значно пов'язані з клінічними факторами, в той час як надмірна експресія 17 мікроРНК була пов’ язана з естроген-рецептор-позитивною стадією I або II раку молочної залози, з хорошим клінічним результатом [25]. Надмірна експресія miR-210 асоційована з підвищеним ризиком рецидиву та зниженим 
шансом безрецидивної виживаності [26], в той час як підвищена експресія miR-155 асоційована 3 поганою післяопераційною виживаністю при раку легенів і в-клітинних лімфомах [27]. Виявлено також, що експресія mir-183, miR-183, miR-182 i miR-96 корелює з прогресуванням раку легені [28]. Експресія miR-200с була пов'язана з загальною виживаністю після операції при колоректальному раку [29].

Логіка математичних моделей взаємодії мікроРНК - білок в онкогенезі. Результати численних лабораторних досліджень свідчать про те, що p53, його результати та дерегульовані ним гени формують украй заплутану мережу сигнальної трансдукції. Експериментальні дані часто представляються взаємовиключними, що ускладнює розуміння основних механізмів взаємодії у такій мережі. Тому було потрібно проведення нових експериментів, планування яких виявилося істотно спрощено попередніми оцінками, заснованими на результатах математичного моделювання. У зв'язку з цим гостро постало питання про створення базових математичних моделей для подібних досліджень, про оцінювання адекватності існуючих і нових математичних моделей, про вибір оптимального рівня їх повноти та складності.

У роботі [30] представлено результати досліджень побудови математичних моделей для вивчення кінетики, регуляторної функції, а також терапевтичного потенціалу мікроРНК при різних хронічних неінфекційних захворюваннях, причому особливе місце відведено р53-залежним мікроРНК. Найбільш важливими для цього дослідження роботи представлено двома основними напрямами: створення та аналіз базових математичних моделей взаємодії мікроРНК-білок виду, i, з іншого боку, розробка і застосування моделей функціонування сигнального шляху р53, що включають у розгляд конкретні р53-залежні мікроРНК. Велика частина базових моделей віднесена до класу малорозмірних, тобто призначених лише для опису найбільш загальних закономірностей функціонування ключових елементів досліджуваних сигнальних шляхів на основі кінетики закону діючих мас МіхаелісаМентен і Хілля.

У роботі першого напряму [31] представлена кінетична модель постранскрипційної регуляції генів за допомогою мікроРНК, що прискорюють деградацію цільових матричних (м)РНК. Адекватність результатів моделювання оцінювалася по відношенню до експериментального прогнозу швидкості розпаду miR-124a, а також експериментально зміненим значенням швидкості розпаду мРНК мішеней людини. В роботі [32] розроблено математичні моделі та виконано аналіз деяких ключових молекулярних механізмів впливу мікроРНК на процес трансляції білка.

Розроблено математичну модель функціонування сигнального шляху, задіяного в регуляторних процесах при раку легені та показано, що мутації двох ключових білків призводять до позитивної регуляції MIR-9 і придушення let-7.

Великий цикл досліджень [33, 34] присвячений як досить загальним питанням побудови моделей взаємодії білок - мікроРНК, так і їхнім контрольним додаткам. Слід зазначити роботи [33], в яких для мереж мРНК - білок - мікроРНК було запропоновано мінімальні математичні моделі взаємодії. У дослідженні [34] автори ілюструють адекватність розробленого ними підходу на прикладі білка р21 і пов'язаних із ним 15 мікроРНК. Уроботах [33, 34] сформовано математичні моделі загального вигляду, а як приклад розглянуто сигнальний модуль, що складається з білків р53, Sirt l n miR-34a. На ряду з цим, представлені математичні моделі чотирьох гіпотетичних механізмів взаємодії мікроРНК із негативним результатом активності p53 білком Sirt [35].

У дослідженні [36] зроблена спроба застосувати інструменти теорії управління при розробці критеріїв контролю зворотного зв'язку для досягнення ідеальної адаптації мережі р53 - Mdm 2 - MIR до збурення р53, підтримки базового рівня р53 i його відновлення. У цій роботі використовується мінімальна модель у припущенні, що мікроРНК прямо або побічно регулюють біохімічний процес, що викликає р53-залежний апоптоз. Як вважають автори мережа p53 - Mdm 2 - MIR, може бути представлена багатостадійним процесом вельми загального вигляду, що має скалярні вхідні сигнали та залежить від змінної, яка управляє. У роботі [37] цей напрям отримав подальший розвиток: розроблено двоконтурну стратегію управління негативним зворотним зв'язком, включаючи регулювання концентрації інсуліну при його впливі на пухлинну клітину. Відзначено, що отримані результати можуть мати значення для планування лабораторних експериментів, націлених на проектування синтетичних схем зворотного зв'язку.

Представлена математична модель [38] ядра модуля р53 - Mdm 2 з трьома мікроРНК - опосередкованими петлями зворотного зв'язку за участю 
MIR-192, MIR-34a i MIR-292. Описані результати чисельних і лабораторних досліджень надають найбільш загальні закономірності функціонування біологічної системи з негативним зворотним зв'язком p53 — білок — інгібітор і позитивним біологічним зворотним зв'язком р53 - мікроРНК. У рамках прийнятої моделі розглянуто можливі стратегії відновлення нормального рівня р53 і р53-залежних від мікроРНК із метою профілактики злоякісних новоутворень. Вивчено варіанти протиракової терапії, пов’язані з гіперактивацією регуляторів апоптозу (p53 і мікроРНК). Показано потенційно високу ефективність антибластомної терапії, мішенню якої є блок-інгібітор р53 — мікроРНК [39].

Отже, аналіз можливих стратегій відновлення нормального рівня р53 і р53-залежних від мікроРНК із метою профілактики злоякісних новоутворенні змінив розуміння експресії генів i створив прецедент для розроблення нових методів діагностики та лікування раку. Видається важливим виявити додаткові потенційні мішені мікроРНК та розробити безпечні та специфічні методи лікування на основі мікроРНК, із тим, щоб

\section{Література.}

1. The c. elegans heterochronic gene lin-4 encodes small RNAs with antisense complementarity to lin-14 / Lee R. C., Feinbaum R. L., Ambros V. // Cell. - 1993. № 75. - P. 843-854.

2. The evolution of controlled multitasked gene networks: The role of introns and other noncoding RNAs in the development of complex organisms / Mattick J. S., Gagen M. J. // Mol Biol Evol. — 2001. — № 18. P. 1611-1630.

3. Systems-based strategies for p53 recovery / Azam M. R., Fazal S.,Ulcah M., et al. // IET Syst biol. — 2018. — № 12 (3). — P. 101-107.

4. MicroRNAs get to the heart of evelopment / Tao G., Martin J. F. // Elife. — 2013. — № 2. — P. e01710.

5. MicroRNAs in vascular aging and atherosclerosis / Menghini R., Stöhr R., Federici M. // Ageing Res Rev. - 2014. — № 17. — P. 68-78.

6. The role of viral and host microRNAs in the Aujeszky's disease virus during the infection process / Timoneda O., Núñez-Hernández F., Balcells I. et al. // PLoS One. — 2014. — № 9. — P. e86965.

7. Human microRNA genes are frequently located at fragile sites and genomic regions involved in cancer / Calin G. A., Sevignani C., Dumitru C. D. et al. // Proc Natl Acad Sci U S A. — 2004. — № 101 (9). — P. 2999-3004. модуляція мікроРНК стала критичним методом для лікування раку [41]. У цьому плані становлять інтерес вивчені варіанти протиракової терапії, пов’язані з одночасною гіперактивацією двох регуляторів апоптозу — p53 і мікроРНК. У рамках прийнятого математичного моделювання показано потенційно високу антибластомну терапію, мішенню якої є білок-інгібітор р53 як основна ланка петлі позитивного зворотного зв’ язку р53 — мікроРНК, а також ініціації метастазування пухлин.

Висновки. 1. МікроРНК являють собою найважливіші регулятори клітинного диференціювання, проліферації і виживання. Зміни в експресії мікроРНК явно пов’язані з прогресуванням численних захворювань людини, зокрема, раку.

2. МікроРНК виконують ключову роль у генезі пухлин як важливі модулятори/демодулятори в клітинних шляхах, регулюючи експресію гена цілі через репресію перекладу або погіршення mRNA. Отже, мікроРНК є привабливими кандидатами на роль прогностичних біомаркерів i терапевтичних мішеней при раку.

8. Long interested element (LINE-1): passenger of driver in human neoplasms? / Rodic N., Burns K. H. // Plos Genetics. — 2013. — № 9 (3). — P. e1003402.

9. MIR-335 directly targets $\mathrm{Rb} 1(\mathrm{PRb} / \mathrm{p} 105)$ in a proximal connection to p53 - dependent stress response / Scarola M., Schoeftner S., Schneider C., et al. // Cancer Res. 2010. — № 70. — P. 6925 - 6933.

10. Khavinson V. K. Peptides, genome, aging / Khavinson V. K. // Adv. Gerontol. — 2014. — № 27 (2). — P. 257-264.

11. The transposon register / Tansizichaiya S., Rahman M.A., Roberts A. P. // Mol. DNA. — 2019. — № 10. — P. 40.

12. Wild type-and mutant p53 proteins in mitohondrial dysfunction: emerging insights in cancer disease / Blandino G., Valenti, Sacconi A., et al. // Semin Cell Dev/Biol. — 2019. — № 23. — P. S 1084.

13. Identification of new p53 target microRNAs by bioinformatics and functional analysis / Bisio A., De Sanctis V., Del Vescovo V., et al. // BMC Cancer. 2013. - № 13. - P. 552.

14. MIR-509-5 joins the Mdm2/p53 feedback loop and regulates cancer cell growth / Ren Z. J., Nong X. Y., Lv. Y. R. et al. // Cell Death Dis. — 2014. — № 5. — P. N0 e 1387.

15. MDMN4 regulation by the let 7 miRNA family in the DNA damage response of glioma cells / Xie C., Chen W., Zhang M. et al. // FEBC left. — 2015. — № 589. - P. 1958-1965. 
16. Molecular regulation of cellular senescence by MicroRNAs: implications in cancer and age-related diseases / Neault M., Couteau F., Bonnean E. et al. // Int. Rev. Cell. Mol. Biol. — 2017. — № 334. P. 27-98.

17. Micro-RNA -16 feedback loop with p53 and Wip 1 can regulate cell fate determination between apoptosis and senescence in DNA damage response/ Issler M. V. C., Mombach J. C. M. // PLoS ONE. - 2017. № 12 . - P. e0/18574.

18. A suppressive role of ionizing - responsive MIR-29c in the development of liver carcinoma via targeting VIP 1 / Wang B., Li D., Sidler C. et al. // Oncotarget. — 2015. — № 6. — P. 9937-9950.

19. Molecular regulation of cellular senescence by MicroRNAs: implications in cancer and age-related diseases / Neault M., Couteau F., Bonnean E. et al. // Int. Rev. Cell. Mol. Biol. — 2017. — № 334. — P. 27-98.

20. MIR 15b/16-2 regulates factors that promotes p53 phosphorylation and augments the DNA damage response following radiation in the oung / Rahman M., Lovat F., Romano G. et al. // J. Biol. Chem. - 2014. — № 289 (1). — P. 26406 - 26416.

21. Downregulation of p53 - inducible micro-RNAs 192, and 215 impairs the p53/ MDM2 autoregulatory loop in multiple myeloma evelopment / Pichiorri F., Snh S. S. Rocci A. et al. // Cancer Cell. — 2010. — № 18. P. 367-381.

22. p53/mdm 2 feedback loop sustains miR-221 expression and distances the response to anticancer treatments in hepatocellular carcinoma / Formari F., Millaz M., Calass M. et al. // Mal. Cancer Res. - 2014. — № 12. P. 203-216.

23. MIR-335 directly targets Rb 1 (PRb/p105) in a proximal connection to p53 - dependent stress response / Scarola M., Schoeftner S. Schneider C. et al. // Cancer Res. 2010. — № 70. — P. 6925-6933.

24. Modulation of microRNA processing by p53 / Suzuki H. I., Yamagata K., Sngimoto K. et al. // Nature. — 2019. — № 460. — P. 529-533.

25. Mapping the regulatory sequences controlling 93 breast cancer-associated miRNA genes leads to the identification of two functional promoters of the Hsamir-200b cluster, methylation of which is associated with metastasis or hormone receptor status in advanced breast cancer / Wee E. J., Peters K., Nair S. S., Hulf T. et al. // Oncogene. — 2012. — № 31. — P. 4182-4195.

26. Global microRNA expression profiling identifies MiR-210 associated with tumor proliferation, invasion and poor clinical outcome in breast cancer / Rothé F., Ignatiadis M., Chaboteaux C. et al. // PLoS One. 2011. — № 6. — P. e20980.

27. High expression of miR-21 and miR-155 predicts recurrence and unfavourable survival in non-small cell lung cancer / Yang M., Shen H., Qiu C. et al. // Eur J Cancer. — 2013. — № 49. — P. 604-615.
28. Down-regulation of miR-183 promotes migration and invasion of osteosarcoma by targeting Ezrin / Zhu J., Feng Y., Ke Z. et al. // Am J Pathol. — 2012. — № 180. — P. 2440-2451.

29. Serum miR-200c is a novel prognostic and metastasispredictive biomarker in patients with colorectal cancer / Toiyama Y., Hur K., Tanaka K. et al. // Ann Surg. 2014. — № 259. — P. 735-743.

30. Mechanistic computational models of microRNA mediated signaling networks in human diseases / Zhao C., Zhang Y., Popel A. S. // J. Mol. Sci. — 2019. — 20. — № 2.

31. Complitional Melling of Post-transcriptional gene regulation by microRNAs / Khamin R., Vincio V. // J. Complitional. Biol. — 2008. — № 15 (3). — P. 305-316.

32. Mathematical modeling of micro-RNA - mediated mechanisms of translocation repression / Zinovyev A., Morozova N., Gorban A. et al. // Exp. Med Biol. 2013. — № 774. — P. 189-224.

33. A systems biology approach to study microRNAregulated gene regulatory networks / Lai X., Bhattacharya A., Scwitz V. et al. // Bio med. Res. International. 2013. — № 703849.

34. Understanding microRNA — mediated gene regulatory networks through mathematical modellity / Lai X., Wolkenhauer O., Vera Jn. // Nucleic Acides Rees. 2016. — № 44 (13). — P. 6019-6035.

35. Modelling MicroRNA - MicroRNA interactions: tithing chemical kinetics equations to microarray data / Luo Z., Azencott R., Zhao Y. // BMC Systems Biol. — № 8 (19).

36. Integral control feedback circuit to the reactivation of malfunctioning p53. / Ooi H. K., Ma L. - 2015. URL:axiv.org/abs 1510.04136.

37. Systems-based strategies for p53 recovery / Azam M. R., Fazal S.,Ulcah M. et al. // IET Syst biol. — 2018. — № 12 (3). — P. 101-107.

38. Mir-192 — weidated positive feedback loop controls the robnethess of stress - induced p53 oscillations breast cancer cells / Moore R., Ooi H. K., Kang T. et al. // Plos Computational Biol. — 2015. — № 11 (12). — P. e 1004652.

39. Гиперактивация сигнального пути р53 и микроРНК: Математическое моделирование вариантов противоопухолевой терапии / Варопаева О. Ф., Лисачёв П. Д., Сенотрусова С. Д. и др. // Математическая биология и биоинформатика. — 2019. — Т. 14.№ 1. - С. 355-372.

40. Чумаков П. М. Белок р53 и его универсальные функции в многоклеточном организме / Чумаков П. М. // Усп. биол. физики. — 2007. — Т. 47. — С. 3-52.

\section{References.}

1. Lee, R. C., Feinbaum, R. L., Ambros, V. (1993). The c. elegans heterochronic gene lin-4 encodes small RNAs with antisense complementarity to lin-14. Cell. 75, 843-54. 
2. Mattick, J. S., Gagen, M. J. (2001). The evolution of controlled multitasked gene networks: The role of introns and other noncoding RNAs in the development of complex organisms. Mol Biol Evol. 18, 1611-30.

3. Azam, M. R., Fazal, S., Ullah, M., Bhatti, A. I. (2018). Systems-based strategies for p53 recovery. IET Syst boil, 12(3), 101-7.

4. Tao, G., Martin, J. F. (2013). MicroRNAs get to the heart of development. Elife, 2, 01710.

5. Menghini, R., Stöhr, R, Federici, M. (2014). MicroRNAs in vascular aging and atherosclerosis. Ageing Res Rev., 17, 68-78.

6. Timoneda, O., Núñez-Hernández, F., Balcells, I. et al. (2014). The role of viral and host microRNAs in the Aujeszky's disease virus during the infection process. PLoS One, 9, 86965.

7. Calin, G. A., Sevignani, C., Dumitru, C. D. et al. (2004). Human microRNA genes are frequently located at fragile sites and genomic regions involved in cancers. Proc Natl Acad Sci USA, 101 (9), 2999-3004.

8. Rodic, N., Burns, K. H. (2013). Long interested element (LINE-1): passenger of driver in human neoplasms? Plos Genetics, 9 (3), 1003402.

9. Scarola, M., Schoeftner, S., Schneider, C., Benetti, R. (2010). MIR-335 directly targets Rb 1 (PRb/p105) in a proximal connection to p53 - dependent stress response. Cancer Res., 70, 6925-33.

10. Khavinson, V. K. (2014). Peptides, genome, aging Adv. Gerontol., 27 (2), 257-64.

11. Tansizichaiya, S., Rahman, M. A., Roberts, A. P. (2019). The transposon register. Mol. DNA, 10, 40.

12. Blandino, G., Valenti, Sacconi, A., Di Agostino, S. (2019). Wild type-and mutant p53 proteins in mitohondrial dysfunction: emerging insights in cancer disease. Semin Cell Dev Biol., 1084.

13. Bisio, A., De Sanctis, V., Del Vescovo, V., Denti, M. A., Jegga, A. G., Inga, A., Ciribilli, Y. (2013). Identification of new p53 target microRNAs by bioinformatics and functional analysis. BMC Cancer.

14. Ren, Z. J., Nong, X, Y., Lv., Y. R. et al. (2014). MIR509-5 joins the Mdm2/p53 feedback loop and regulates cancer cell growth. Cell Death Dis., 5, 1387.

15. Xie, C., Chen, W., Zhang, M., Cai, Q., Xu, W., Li, X., Jiang, S. (2015). MDMN4 regulation by the let 7 miRNA family in the DNA damage response of glioma cells. FEBC left, 589 (15), 1958-65.

16. Neault, M., Couteau, F., Bonnean, E., De Guire, V., Mallette, F, A. (2017). Molecular regulation of cellular senescence by MicroRNAs: implications in cancer and age-related diseases. Int. Rev. Cell. Mol. Biol., 334, 27-98.

17. Issler, M. V. C., Mombach, J. C. M. (2017). MicroRNA-16 feedback loop with p53 and Wip 1 can regulate cell fate determination between apoptosis and senescence in DNA damage response. PLOS ONE, 12, 18574.
18. Wang B., Li D., Sidler C. et al. (2015). A suppressive role of ionizing - responsive MIR-29.c in the development of liver carcinoma via targeting VIP 1 Oncotarget., 6, 9937-50.

19. Neault, M., Couteau, F., Bonnean, E., De Guire, V., Mallette, F. A. (2017). Molecular regulation of cellular senescence by MicroRNAs: implications in cancer and age-related diseases. Int. Rev. Cell. Mol. Biol., 334, 27-98.

20. Rahman M., Lovat F., Romano G. et al. (2014). MIR 15b/16-2 regulates factors that promotes p53 phosphorylation and augments the DNA damage response following radiation in the lung. J. Biol. Chem., 289 (1), 26406-416.

21. Pichiorri, F., Snh, S. S., Rocci, A. et al (2010). Downregulation of p53 - inducible micro-RNAs 192, and 215 impairs the p53/ MDM2 autoregulatory loop in multiple myeloma evelopment. Cancer Cell, 18, 367-81.

22. Formari, F., Millaz, M., Calass, M., et al. (2014). p53/ mdm 2 feedback loop sustains miR-221 expression and distances the response to anticancer treatments in hepatocellular carcinoma. Mal. Cancer Res., 12, 203-16.

23. Scarola, M., Schoeftner, S., Schneider, C. et al (2010). MIR-335 directly targets Rb 1 (PRb/p105) in a proximal connection to p53 — dependent stress response. Cancer Res., 70, 6925-33.

24. Suzuki, H. I., Yamagata, K., Sngimoto, K. et al. (2009)/ Modulation of microRNA processing by p53. Nature, 460, 529-33.

25. Wee, E. J., Peters, K., Nair, S. S. et al. (2012). Mapping the regulatory sequences controlling 93 breast cancerassociated miRNA genes leads to the identification of two functional promoters of the Has-mir-200b cluster, methylation of which is associated with metastasis or hormone receptor status in advanced breast cancer. Oncogene, 31, 4182-95.

26. Rothé, F., Ignatiadis, M., Chaboteaux, C. et al. (2011). Global microRNA expression profiling identifies MiR210 associated with tumor proliferation, invasion and poor clinical outcome in breast cancer. PLoS One. 6, 20980.

27. Yang, M., Shen, H., Qiu, C., Ni, Y, Wang, L., Dong, W., Liao, Y., Du, J. (2013). High expression of miR-21 and miR-155 predicts recurrence and unfavourable survival in non-small cell lung cancer. Eur J Cancer, 49, 604-15.

28. Zhu, J., Feng, Y., Ke, Z., Yang, Z., Zhou, J., Huang, X., Wang, L. (2012). Down-regulation of miR-183 promotes migration and invasion of osteosarcoma by targeting Ezrin. Am J Pathol., 180, 2440-51.

29. Toiyama, Y., Hur, K., Tanaka, K., Inoue, Y., Kusunoki, M., Boland, C. R., Goel, A. (2014). Serum miR-200c is a novel prognostic and metastasis-predictive biomarker in patients with colorectal cancer. . Ann Surg ., 259, 735-743.

30. Zhao, C., Zhang, Y., Popel, A. S. (2019). Mechanistic computational models of microRNA - mediated signaling networks in human diseases Int J. Mol. Sci. 20(2), doi: 10. 3390 / ijms 20020421 
31. Khamin, R., Vincio, V. (2008). Complitional Melling of Post-transcriptional gene regulation by microRNAs J. Complitional. Biol., 15 (3), 305-16.

32. Zinovyev, A., Morozova, N., Gorban, A. et al. (2013). Mathematical modeling of microRNA - mediated mechanisms of translocation repression. Adv., Exp. Med Biol., 774, 189-224.

33. Lai, X., Bhattacharya, A., Scwitz, V. et al. (2013). A systems biology approach to study microRNA regulated gene regulatory networks. Bio med. Res. International Ast., 703849.

34. Lai, X., Wolkenhauer, O., Vera, Jn. (2016). Understanding microRNA - mediated gene regulatory networks through mathematical modellity. Nucleic Acides Rees., 44(13), 6019-35.

35. Luo, Z., Azencott, R., Zhao, Y. (2014). Modelling MicroRNA - MicroRNA interactions: tithing chemical kinetics equations to microarray data. BMC Systems Biol., 8 (19).
36. Ooi, H. K., Ma, L. (2015). Integral Control Feedback Circuit for the Reactivation of Malfunctioning p53 Pathway. G-bio. MN.

37. Azam, M. R., Fazal, S., Ulcah, M., et al. (2018). Systemsbased strategies for p53 recovery. IET Syst boil, 12 (3), 101-7.

38. Moore, R., Ooi, H. K., Kang, T. et al. (2015). Mir-192 weidated positive feedback loop controls the robnethess of stress - induced p53 oscillations breast cancer cells. Plos Computational Biol., 11 (12), 1004652.

39. Varopaeva, O. F., Lysachev, P. D., Senotrusova, S. D. et al. (2019). n/modelyrovanye varyantov protyvoopukholevoi terapyy. [Hyperactivation of the p53 signaling pathway and micro RNA: Mathematical modeling of antitumor therapy options.]. Matematycheskaia byolohyia y byoynformatyka, Vol. 14 (1), 355-72. [In Russian].

40. Chumakov, P. M. (2007). Belok r53 y eho unyversalnые funktsyy v mnohokletochnom orhanyzme. [The p53 protein and its universal functions in a multicellular organism]. Usp. byol. fyzyky, 47, 3-52. [In Russian]. 